\title{
RAZVOJ SPECIALNIH SIL SV IN IZKUŠNJE IZ AFGANISTANA
}

\author{
DEVELOPMENT OF SAF SPECIAL FORCES \\ AND EXPERIENCES FROM AFGANISTAN
}

Povzetek Slovenska vojska je od osamosvojitve do danes dosegla velik napredek pri razvoju zmogljivosti specialnih sil, kar s svojo vrhunsko usposobljenostjo in pripravljenostjo ter interoperabilnostjo s sorodnimi enotami Nata v praksi nenehno potrjuje njena Enota za specialno delovanje (ESD). Potencial enote se kaže predvsem pri izpolnjevanju obveznosti RS v mednarodnih operacijah in na misijah. Članek na primeru delovanja ESD ponuja razmislek o povezanosti med razvojnim konceptom specialnih sil SV ter njihovo resnično »in field« uporabo. Najvidnejši primer delovanja ESD v mirovnih operacijah in na misijah je bila napotitev v sklopu dvajsetega slovenskega kontingenta v operacijo Isafa. Element ESD je kot del Desete skupne bojne skupine za specialno delovanje pod vodstvom komponentnega poveljstva specialnih sil Isafa prvič v zgodovini SV sodeloval v operacijah specialnih sil Nata, in sicer v smislu nekonvencionalnega delovanja, s temeljno nalogo vojaške pomoči afganistanskim varnostnim silam. SV je z delovanjem elementa ESD v sklopu specialnih sil Isafa potrdila svoje zmogljivosti $\mathrm{v}$ praksi in tako $\mathrm{v}$ zahtevnem mednarodnem okolju dokazala, da je strateški koncept $\mathrm{RS}$, povezan z razvojem specialnih sil SV, pravilen in predvsem uresničljiv.

Ključne Enota za specialno delovanje, specialno delovanje, protiuporništvo, vojaška besede pomoč, Nato SOF, specialne sile Isafa, CSOTF-10.

Abstract Since Slovenia's independence to date, the Slovenian Armed Forces (SAF) achieved significant progress in developing the capabilities of special forces. This is being continuously confirmed by SAF Special Operations Unit (SOU) in practice with its superior competence and readiness as well as the interoperability with similar NATO units. The unit's potential is mainly reflected in the fulfilment of the obligations of the Republic of Slovenia in international operations and missions. Using the example of SOU operations, the article provides a reflection on the relationship between the 
development concept of SAF Special Operations Unit and its actual in field use. The most visible example of SOU activities in peacekeeping operations and missions was the deployment of the $20^{\text {th }}$ Slovenian contingent to the ISAF operation. For the first time in the history of the SAF, the SOU element which was subordinated to the Combined Special Operations Task Force 10 led by Combined Forces Special Operations Component Command - Afghanistan participated in NATO special operations forces in terms of unconventional operations. Its basic task was to provide military assistance to the Afghan security forces. With the engagement of SOU element within ISAF special forces the SAF confirmed its capabilities in practice and proved in the international environment that the strategic concept of the Republic of Slovenia associated with the development of SAF special forces was accurate and fully implementable.

Key words Special Operations Unit, special operations, counter-insurgency, military assistance, NATO SOF, ISAF special forces, CSOTF-10.

Uvod Prevladujoče stališče med različnimi obrambnimi in varnostnimi subjekti v svetu je, da spreminjajoče se varnostno okolje pred nas postavlja vsestranske in zapletene izzive, ki jih je težko predvideti. Zelo raznolike in nekonvencionalne grožnje lahko ogrozijo širšo mednarodno stabilnost in povzročijo dolgotrajno konfliktno stanje. Specialne sile so zato dejaven instrument, ki je idealno prilagojen nejasnemu in dinamičnemu okolju, po drugi strani pa ohranja svobodo delovanja z uporabo načela varčnosti sil. Poleg tega imajo specialne sile enkratno zmožnost za izvedbo nalog v okoljih, v katerih so konvencionalne sile v primerjavi s specialnimi v strateško ali operativno slabšem položaju (NSCC, 2008).

Kot piše Beršnak, zagotavljajo specialne sile nacionalnim državam strateške zmogljivosti, ki so »/.../ idealno orodje za odgovor na nove pojavne oblike varnostnih groženj. Vendar predstavljajo tovrstne sile določeno stopnjo političnega in fizičnega tveganja, zaradi česar morajo nacionalne oborožene sile zagotoviti, da so te strukture kar se da funkcionalne in učinkovite, da bi uspešno izvedle svoje poslanstvo« (Beršnak, 2010, str. 6).

Temeljni namen članka je prikazati povezavo med strateškim konceptom specialnih sil SV ter delovanjem ESD, predvsem na primeru opravljanja taktičnih nalog v Natovih operacijah kriznega odzivanja.

Trije glavni cilji članka so: 1) pregled glavnih dejavnikov, ki vplivajo na strateški razvoj specialnih sil SV; 2) prikaz evolucije specialnih sil SV; 3) ugotavljanje konvergence med strateško zasnovo oziroma konceptom specialnih sil SV in namensko uporabo ESD. Dodatna dva cilja pa sta: 4) spodbuda za širšo razpravo o vsebini, namenjeni za podporo razvoju glavnih normativnih dokumentov; 5) seznanitev širše zainteresirane strokovne javnosti s strateškim konceptom specialnih sil in njegovo uveljavitvijo v SV. 


\section{PREGLED GLAVNIH DEJAVNIKOV, KI VPLIVAJO NA STRATEŠKI RAZVOJ SPECIALNIH SIL SV}

Naloge Slovenske vojske so jasno opredeljene z Zakonom o obrambi, vendar se glede na razmeroma hitro spreminjajoče se sodobne vire ogrožanja in grožnje ter glede na zmanjševanje finančnih virov, ki jih država lahko namenja za obrambne izdatke, RS nenehno srečuje z zamislijo o preoblikovanju oboroženih sil (oziroma poskusi ${ }^{1}$ preoblikovanja).

Na preoblikovanje oboroženih sil, znotraj katerega se razvijajo tudi specialne sile, vplivajo različni dejavniki ${ }^{2}$. V članku se bomo omejili predvsem na dva, in sicer na varnostne grožnje in obrambne izdatke. Prvi je za razvoj specialnih sil znotraj širšega konteksta oboroženih sil pomemben, ker so te zaradi svojih izjemnih zmogljivosti, kot sta prilagodljivost in okretnost, idealno orodje za odgovor na kompleksne izzive, ki se pojavljajo v sodobnem nejasnem in dinamičnem okolju. Podobno velja tudi za drugi dejavnik, saj lahko v smislu učinka cost benefit ${ }^{3}$ specialne sile zaradi svojih značilnosti pri nekaterih vsestranskih izzivih dosežejo hitrejše in zato boljše učinke kot druge tradicionalne zvrsti.

\subsection{Spreminjanje varnostnih groženj}

Veliko je bilo že napisano o spreminjanju varnostnih groženj, ki namesto tradicionalnih vrst, kot smo jih poznali predvsem do konca hladne vojne, prevzemajo vse bolj nekonvencionalne oblike.

Resolucija o strategiji nacionalne varnosti Republike Slovenije - ReSNV-1 (Državni zbor RS, 2010) v 4. poglavju dokaj obsežno analizira vire ogrožanja in tveganja za nacionalno varnost Republike Slovenije, vendar bi bil za njihov kratek oris primeren tudi povzetek Resolucije o splošnem dolgoročnem programu razvoja in opremljanja Slovenske vojske do leta 2025 (ReSDPRO SV 2025), ki navaja, da se je » /.../ v evro-atlantskem prostoru močno zmanjšala verjetnost izbruha oboroženih meddržavnih spopadov. Vojaške grožnje se bodo pojavljale predvsem v obliki lokalnih in regionalnih nestabilnosti, ki lahko hitro prerastejo svoj okvir. Sodobne

\footnotetext{
„Osrednja značilnost dosedanje prakse je bila, da se je velikokrat projektiralo in odločalo z neustrezno podporo ali brez ustrezne podpore, ki mora spremljati politične in strokovne odločitve in postopke oblikovanja razvojnih programov, ter da je bil pri projektiranju strukture sil najpogosteje uporabljen ad hoc pristop, usmerjen $v$ delne ali kratkoročne rešitve.

Menim, da je bil temeljni problem pri dosedanjem projektiranju preoblikovanja strukture sil Slovenske vojske $v$ nejasnih ciljih in viziji, $v$ predimenzionirani zasnovi obsega, v neizoblikovani strategiji preoblikovanja in v prepogostem spreminjanju težišč. Zaradi tega je bil stroškovni del projektiranja močno omejen ali zapostavljen. S spreminjanjem težišč preoblikovanja in razvojnih prioritet pa se je projektiranje strukture sil vedno znova vračalo na začetek in bilo ujeto v začarani krog s skromno realizacijo projektov. Dosedanje preoblikovanje strukture sil je potekalo po jedrih, del teh projektov preoblikovanja pa ni bil končan. Sistem dolgoročnega načrtovanja financiranja in razvoja na obrambnem področju, ki je veljal v nekdanji skupni državi, je bil leta 1991 opuščen, novi pa dolgo ni bil postavljen « (Šteiner, 2013, str. 67).

2 Avtorji navajajo tri glavne sklope: varnostne grožnje, javna podpora in druge dejavnike vpliva, med katere štejejo: mednarodne organizacije, regionalne pobude za sodelovanje, vpliv vodilnih članic raznih povezav, pristne nacionalne potrebe, obrambne izdatke, razpoložljivost človeških virov ter vpliv akterjev civilne družbe (Prezelj idr., 2015, str. 27).

3 Razmerje med vložkom na eni strani in zmogljivostjo na drugi.
} 
grožnje prevzemajo vse bolj hibridno obliko, njihov značaj pa zaradi močnih globalizacijskih vplivov postaja večplasten in mednaroden, takšni pa so tudi njihovi učinki« (Državni zbor RS, 2010, str. 7).

\subsection{Zmanjševanje finančnih virov}

Republika Slovenija je bila zaradi slabih makroekonomskih razmer v preteklih letih prisiljena občutno zmanjšati finančne vire, namenjene obrambnim izdatkom. Obrambni proračun RS se je tako z 1,65 odstotka BDP leta 2010 zmanjšal na 1,09 odstotka leta 2013. V nominalnih zneskih to pomeni zmanjšanje s 582 milijonov evrov (2010) na 382 milijonov evrov (2013) oziroma za eno tretjino. Zmanjševanje obrambnih izdatkov pa se je na podlagi sprejetih proračunov za leti 2014 in 2015 še nadaljevalo. Za leto 2015 je za področje obrambe namenjenih le še 366 milijonov evrov, kar je 0,95 odstotka bruto domačega proizvoda (MO, 2015, str. 3).

\subsection{Preoblikovanje oboroženih sil}

Kljub trenutni težnji po zmanjševanju finančnih virov je treba omeniti, da gre pri obrambnem prestrukturiranju za neprekinjen proces, saj lahko, kot piše Garb, vidimo v državah našega širšega geopolitičnega prostora ${ }^{4}$, da

/.../ so reforme obrambnega sistema stalnica $v$ vseh dolgoročnih in tudi kratkoročnih načrtih. Trend reform obrambnih zmogljivosti gre $v$ smeri prestrukturiranja sil iz klasičnih manevrskih enot, namenjenih za obrambo ozemlja, v sodobne, hitro odzivne, prožne, mobilne, premestljive, s sodobnimi oborožitvenimi sistemi opremljene, interoperabilne in $v$ zavezniške strukture integrirane sile, sposobne izvajanja širokega spektra operacij različnih stopenj intenzivnosti, ekspedicijskega in asimetričnega vojskovanja, delovati kot stabilizacijske sile v mednarodnih operacijah in misijah (MOM) in tudi zagotavljati vojaško obrambo nacionalnega ozemlja. Pri preoblikovanju predstavljajo sprejeti Natovi standardi eno od temeljnih vodil, s katerimi se zagotavljajo interoperabilnost, robustnost, visoka stopnja zaščite sil in mobilnosti, opremljenost in podpora (Garb, 2012, str. 76).

Tudi Šteiner ugotavlja, da »/.../ spreminjanje in dopolnjevanje vojaške organiziranosti spadata med osrednje razvojne izzive in dejavnosti na obrambnem področju v mnogih državah« (2013, str. 52) ter da je

/.../ preoblikovanje strukture sil vojske odsev ogroženosti in drugih vplivov okolja, tehnično tehnološkega razvoja, funkcijskih potreb in življenjskega cikla določene vojaške strukture (enote, rodu, zvrsti). Ni vojaške organiziranosti, ki bi bila primerna za ves čas. Zato jo je treba nenehno prilagajati spremembam okolja in ogroženosti, spremembam v tehnologiji delovanja, vrstam in značilnostim bojnih sistemov ter fazam razvojnega cikla vojske. Navedeno pomeni, da je projektiranje organiziranosti strukture sil stalen, ponavljajoč se proces. S sedanjim preoblikovanjem je tudi Slovenska vojska na razvojni prelomnici in pred pomembnimi izzivi (Šteiner, 2013, str. 69).

4 Govora je o državah Avstrija, Hrvaška, Italija, Madžarska in Slovenija. 


\section{STRATEŠKI RAZVOJ SPECIALNIH SIL}

\subsection{Specialne sile Nata kot samostojna komponenta}

Beršnak poudarja, da se na nacionalne specialne sile kot na strateško orodje gleda predvsem skozi prizmo nacionalnih interesov,

/.../ toda v globalno povezanem svetu 21. stoletja so mednarodne varnostne povezave postale ključne za soočanje s spreminjajočimi se globalnimi varnostnimi tveganji in grožnjami, ki so takšne narave, da ni nacionalne države, ki bi jih bila sposobna reševati samostojno. Tako so specialne sile zveze Nato postale pomemben dejavnik znotraj partnerstva, ki služijo kot temelj za povezovanje, razvoj, urjenje in sodelovanje nacionalnih specialnih sil pri soočanju z globalnimi varnostnimi tveganji in grožnjami (Beršnak, 2010, str. 6).

»Do konca leta 2006 so enote za specialno delovanje držav članic zveze Nato delovale samo v sestavi odzivnih sil zveze Nato $\left(\mathrm{NRF}^{5}\right)$, ki so bile vzpostavljene na vrhunskem zasedanju v Pragi leta 2002« (Beršnak, 2010, str. 26). Njihovo delovanje je bilo organizacijsko povezano samo s posamezno komponentno zvrstjo, iz katere so po nacionalni strukturi izhajale.

$\mathrm{Na}$ podlagi spoznanj in izkušenj vodilnih članic Nata, predvsem v operacijah specialnih sil v Iraku in Afganistanu, je bila leta 2006 na vrhunskem zasedanju v Rigi sprejeta odločitev o preoblikovanju specialnih sil (Nato SOF ${ }^{6}$ Transformation Initiative), s katerim bi dosegli večjo medsebojno primerljivost in večjo zmožnost skupnega delovanja. Ta cilj naj bi bil dosežen predvsem s skupnim usposabljanjem, opremljanjem ter vzpostavitvijo in doseganjem skupnih standardov. S tem namenom je bil leta 2007 ustanovljen tudi Koordinacijski center za specialne operacije Nata $\left(N S C C^{7}\right)$, ki se je v začetku leta 2010 preoblikoval v Poveljstvo za specialno delovanje Nata $\left(N S H Q^{8}\right)$. To je postalo, poleg prvotnega namena, zaradi katerega je nastal Koordinacijski center za specialne operacije Nata, tudi osrednje telo za vodenje in usklajevanje Natovih specialnih operacij. Njegov namen je predvsem optimizirati uporabo specialnih sil zavezništva in zagotoviti zmogljivosti operativnega poveljevanja skladno z usmeritvami SACEUR ${ }^{I I}$.

Hkrati z oblikovanjem organizacijske strukture specialnih sil je Nato začel tudi oblikovanje normativnih podlag. Tako je, kot navaja Paternus, Severnoatlantski svet leta 2006 kot izhodišče za uvedbo skupnih standardov sprejel dokument $\mathrm{MC}^{9}$ 437/1 Special Operations Policy, ki pomeni temelj za oblikovanje skupne Natove doktrine za specialne operacije. Ta je bila izdana leta 2008, in sicer v obliki AJP ${ }^{10}$

\footnotetext{
NRF: Nato Response Forces.

6 SOF: Special Operations Forces.

NSCC: Nato SOF Coordination Centre.

8 NSHQ: Nato Special Operations Headquarters.

9 MC: Military Committee.

${ }^{10}$ AJP: Allied Joint Publication.
} 
3.5 - Združena zavezniška doktrina specialnih operacij (Allied Joint Doctrine for Special Operations), za katero je bil proces potrditve oziroma ratifikacije končan leta 2009 (Paternus, 2010, str. 70).

Avgusta leta 2010 je SHAPE ${ }^{11}$ za povečanje interoperabilnosti izdal skupne standarde za specialne sile (ACO11 FORCE STANDARDS VOLUME X - SPECIAL OPERTAIONS FORCES), ki z vidika bistvenih operativnih zmogljivosti natančneje opredeljujejo standarde zmogljivosti specialnih sil.

Leta 2011 je Severnoatlantski svet na podlagi izkušenj, pridobljenih v prvih letih delovanja Poveljstva za specialno delovanje Nata, sprejel nov MC 437/2 Special Operations Policy. Na njegovi podlagi je leta 2013 nastal tudi prvi popravek (Edition A Version 1) Združene zavezniške doktrine specialnih operacij (AJP 3.5). Popravek gre leta 2015 v postopek potrditve oziroma ratifikacije tudi v RS.

Organizacijska sprememba, ki je najbolj vidna v dosedanjem razvoju specialnih sil Nata je, da so se te s preoblikovanjem oblikovale kot samostojna komponenta, kar jih postavlja ob bok preostalim trem tradicionalnim komponentam ${ }^{12}$.

\subsection{Razvoj specialnih sil SV kot samostojnega rodu ${ }^{13}$}

Dosedanji razvoj sil za specialno delovanje SV oziroma ESD kot nosilca specialnega delovanja SV bi lahko razdelili na štiri obdobja.

Prvo obdobje razvoja je trajalo nekako od leta 1990, ko se je 30. razvojna skupina (27. zaščitne brigade TO SRS) začela preoblikovati v 1. specialno brigado MORiS (leta 1992), pa vse do oblikovanja Odreda za specialno delovanje (v nadaljevanju OdspD) leta 1998 iz Odreda za hitre intervencije 1. specialne brigade MORiS. Za to obdobje je bila značilna predvsem organizacijska struktura, znotraj katere so bili samostojni odredi sestavljeni po pehotnem modelu iz čet, vodov in oddelkov. Vendar je bila organizacija brigade za tisti čas razmeroma napredna, in sicer v modularnem smislu, saj je bila ta tudi rodovsko podprta, kar je danes značilno za strukturo sil SV za bojevanje. Naloge enote so bile naravnane predvsem na varovanje političnega vrha RS in naloge hitrega posredovanja.

\footnotetext{
${ }^{11}$ Nekatere termine oziroma okrajšave zaradi njihove splošno razširjene rabe namenoma uporabljam v izvirniku.

12 Kopenske, zračne in pomorske sile.

13 Želel bi opozoriti, da specialne sile v SV uradno nimajo potrjenega statusa samostojnega rodu, vendar sem pri proučevanju nekaterih glavnih politično-strateških dokumentov, kot sta SOPR 2013-2018 in Vojaška doktrina, zasledil, da so specialne sile SV v sklopu zmogljivosti za bojevanje postavljene ob bok drugim rodovom.

Tako SOPR 2013-18 v 4. poglavju (Vojaške zmogljivosti) navaja: „SV bo v okviru zmogljivosti za bojevanje v obravnavanem srednjeročnem obdobju razvijala predvsem pehotne zmogljivosti (motorizirane, srednje, gorske) in zmogljivosti specialnih sil. Zadržane bodo omejene tankovske zmogljivosti, ki bodo prednostno namenjene usposabljanju pehotnih enot« (Vlada RS, 2013, str. 13). Vojaška doktrina v 5. poglavju (Vrste sil) navaja: "V sile za bojevanje spadajo oklepne enote, pehotne enote in enote za specialno delovanje« (Furlan idr., 2006, str. 26).
} 
Naslednje obdobje obsega čas od leta 1998 do konca leta 2003, ko se je enota začela pripravljati za napotitev v MOM, in sicer za operacijo Isafa. Ob oblikovanju je OdspD dobil novo poslanstvo in temeljne naloge, prav tako je prevzel tudi novo organizacijsko strukturo, ki je bila ustreznejša za opravljanje predvidenih temeljnih nalog specialnega bojevanja. V tem obdobju so poleg novih normativnih dokumentov, ki so urejali delovanje enote, nastali tudi novi programi za usposabljanje. Tako se je enota tudi konceptualno začela približevati modernim specialnim enotam držav Nata. V tem obdobju je enota postavila solidne temelje, na katerih je začela nadgrajevati svojo organizacijsko strukturo, hkrati pa se preimenuje v Enoto za specialno delovanje.

Tretje obdobje se je začelo leta 2004 s prvo napotitvijo pripadnikov enote v MOM, in sicer v operacijo Isafa, kateri so razmeroma hitro sledile še napotitve v operacije NTM-I ${ }^{14}$ v Iraku, Unifil11 v Libanonu, Althea11 v Bosni in Eufor11 v Čadu. Kot pomembno dejstvo je treba izpostaviti, da ESD oziroma njegovi posamezni elementi $\mathrm{v}$ nobeni od tedanjih operacij niso opravljali temeljnih nalog svojega poslanstva, torej specialnega delovanja, temveč so opravljali predvsem naloge s seznama konvencionalnih vojaških nalog (Vlada RS, 2006, str. 25), v sklopu katerih je enota pridobila dragocene izkušnje in se dokazala v najzahtevnejših okoljih. To obdobje je trajalo do začetka leta 2008. Zaznamovalo ga je organizacijsko prestrukturiranje sil SV, med katerim je bila enota večkrat prepodrejena, in sicer iz 1. brigade v Obveščevalnoizvidniški bataljon (v nadaljevanju OIB) in nazadnje pod Poveljstvo sil. V tem času se je bistveno spreminjalo tudi njeno poslanstvo, predvsem med prepodreditvijo pod OIB, ko so bile v ospredju predvsem naloge globinskega izvidništva (Vlada RS, 2005, str. 26). S sprejetjem Vojaške doktrine pa se je osredotočenost poslanstva vrnila v specialno delovanje (Furlan idr., 2006, str. 50).

Zadnje, četrto obdobje razvoja ESD se začne z organizacijsko prepodreditvijo pod Poveljstvo sil v začetku leta 2008 in se časovno ujema z razvojem organizacijske strukture specialnih sil Nata. Za to obdobje je značilno predvsem aktivno približevanje ESD specialnim silam Nata, znotraj katerega je SV začela tudi načrtovanje in vzpostavljanje ciljnih zmogljivosti specialnih sil.

Kot vrhunec razvoja specialnih sil bi lahko označili delovanje ESD v komponenti specialnih sil operacije Isafa (ISAF $\mathrm{SOF}^{15}$ ), ki bo natančneje opisano v nadaljevanju prispevka.

\section{UPORABA ENOTE ZA SPECIALNO DELOVANJE V MOM}

\subsection{Podpora konvencionalnemu delovanju}

ESD je aktivno udeležena v delovanju SV v MOM od leta 2004, ko je v operacijo Isafa napotila prve pripadnike. Od takrat je enota opravljala naloge še v Iraku, Bosni

\footnotetext{
${ }^{14}$ NTM - I: Nato Training Mission - Iraq.

15 SOF: Special Operations Forces.
} 
in Hercegovini, Libanonu, Čadu, na Kosovu in v Maliju. Naloge je opravljala tako znotraj operacij Nata, Evropske unije in OZN.

Naloge, ki jih je opravljala ESD, spadajo predvsem v konvencionalne vojaške naloge. Čeprav so bile nekatere naloge delno primerljive s specialnim delovanjem, pa zaradi konteksta izvedbe nikakor niso imele tega predznaka. Med nalogami in specialnim delovanjem lahko potegnemo nekatere vzporednice/lahko najdemo nekatere primerjave. Tako je glede na analizo delovanja enot za specialno delovanje Nata v vojaški operaciji Trajna svoboda (Enduring Freedom) Paternus ugotovil primerljivost nalog ESD v Isafu, ki so obsegale:

- globinsko izvidovanje in obveščevalne operacije,

- operacije bojnega iskanja in reševanja,

- iskanje in uničenje skrivališč orožja in streliva,

- urjenje pripadnikov zavezniških sil (Paternus, 2010, str. 64).

Do podobnih ugotovitev je prišel Rode, ki je poudaril, da spadajo naloge, ki jih je ESD izvajal v MOM »/.../ predvsem med naloge vojaške pomoči (od SVNKON 7 ISAF-OMLT dalje ${ }^{16}$, NTM-I), delno med izvidniško delovanje (npr. Afganistan SVNKON 1 in 2 ISAF, Libanon UNIFIL SVNKON 1, ALTEHEA SVNKON 1 in ČAD/CAR SVNKON 1). V Afganistanu je ESD izvajala tudi bojno iskanje in reševanje (Afganistan SVNKON 1 in 2 ISAF) in informacijske operacije (INFOOPS, SVNKON 11 ISAF)« (Rode, 2011, str. 50).

Tako je dotedanje delovanje v MOM služilo tudi kot nekakšen poligon za ugotavljanje sposobnosti ESD za izvajanje specialnega delovanja. Kot ugotavlja Paternus, so bili pripadniki ESD že takrat »/.../ ustrezno opremljeni, usposobljeni in pripravljeni za izvajanje specialnega delovanja« (Paternus, 2010, str. 64).

\subsection{Specialno delovanje}

V začetku leta 2012 je ESD začela delovati v sklopu komponentnega poveljstva specialnih sil Isafa, in sicer s po štirimi pripadniki ESD na kontingent. Ti so inštruktorske naloge opravljali $\mathrm{v}$ vadbenem centru specialnih policijskih enot $\left(\mathrm{SPTC}^{17}\right)$ afganistanske policije. Pripadniki ESD so te naloge opravljali do septembra 2013, ko je Isaf umaknil koalicijske inštruktorje iz vadbenega centra v Wardaku zaradi nezmožnosti zagotavljanja ustreznih razmer za njihovo delovanje.

Slovenska vojska je septembra 2013 napotila ESD v komponentno poveljstvo specialnih sil Isafa, v katerem je v sklopu Desete skupne bojne skupine za specialno delovanje $\left(C S O T F-10^{18}\right)$ s še šestimi drugimi državami Nata ${ }^{19}$

\footnotetext{
${ }^{16}$ Kljub vsem zaslugam SVNKON 14 Isafa, ki je leta 2010 začel usposabljati bataljon afganistanske vojske, je treba poudariti, da je ESD usposabljala afganistansko vojsko že leta 2006. Prav tako so pripadniki ESD usposabljali pripadnike iraške vojske na misiji NTM -I v Iraku leta 2006.

17 SPTC: Special Police Training Center.

18 CSOTF-10: Combined Special Operations Task Force - 10

19 ZDA, Romunija, Madžarska, Estonija, Slovaška, Hrvaška.
} 
sodelovala v neposredni podpori bojnemu delovanju afganistanskih varnostnih sil. Udeležba SV je trajala do konca junija 2014, ko se je še zadnji pripadnik ESD vrnil v domovino. Delovanje v tej bojni skupini je bilo zaradi značaja operacije Isafa (zadnja faza - prenos odgovornosti za varno okolje na ANSF) zelo zahtevno, kar bo podrobno opisano v nadaljevanju kot pomoč za razumevanje velikih zmogljivosti specialnih sil.

\subsection{Delovanje elementa ESD v sklopu Desete skupne bojne skupine za specialno delovanje}

Konec leta 2011 so se zaradi vse slabšega makroekonomskega položaja v državi pojavile težnje po zmanjšanju stroškov tudi za MOM. Tako se je sredi leta 2012 pojavil predlog, da bi SV v Isaf napotila element ESD kot element specialnih sil SV in se v povezavi s strukturami specialnih sil Nata usmerila v specialno delovanje. Takšno sodelovanje bi zaradi višje vrednosti ponderja elementov specialnih sil omogočilo, da bi ob točkovno enakem prispevku v podporo operaciji Isafa občutno zmanjšali moštvo celotnega kontingenta.

\section{Organizacija elementa ESD}

SV je v sklopu ESD do leta 2010 za izpolnjevanje obveznosti RS do sistema kolektivne obrambe Nata razvila cilj zmogljivosti, s katerim je do konca leta 2013 zagotavljala taktično skupino za specialno delovanje (v nadaljevanju TSSD). Ta je bila sestavljena iz treh elementov, in sicer iz 1) elementa za podporo poveljevanju in kontroli, 2) bojnega elementa ter 3 ) elementa bojne podpore in zagotovitve delovanja.

Po preizkušenem modelu TSSD je ESD za udeležbo v operaciji Isafa organizirala element za specialno delovanje SV (v nadaljevanju element ESD), in sicer z enakimi tremi sestavnimi deli.

Celoten element ESD v deseti skupni bojni skupini za specialno delovanje je štel 18 pripadnikov. Od tega so štirje sestavljali element za podporo poveljevanju in kontroli, in sicer dva v poveljstvu skupine ter dva v poveljstvu Odreda za specialno delovanje vzhod $\left(S O T G^{20}-E\right)$. Bojni element je štel dvanajst ljudi, dodana pa sta mu bila še dva pripadnika, in sicer usmerjevalec združenega ognja ter logistik. Vseh štirinajst pripadnikov je delovalo v skupni (mišljeno v smislu Combined) enoti, imenovani Taktična skupina za specialno delovanje $\left(S O T U^{21}\right)$, v kateri so sodelovali s pripadniki ameriških kopenskih specialnih sil22.

\section{Priprave na napotitev}

ESD je začela organizacijske in izvedbene priprave za udeležbo v operaciji Isafa že novembra 2012, marca 2013 pa je v sodelovanju s tretjim bataljonom Desete skupine

\footnotetext{
${ }^{20}$ SOTG: Special Operations Task Group.

${ }^{21}$ SOTU: Special Operations Task Unit.

22 SF OD-A: Special Forces Operational Detachment Alpha.
} 
specialnih sil OS ZDA (3-10 SFG(A)23) izvedla taktično vajo LYNX 2013. Na vaji je preverila ter potrdila zmogljivosti elementa ESD za specialno delovanje ter združeno bojevanje rodov v podporo nalogam protiuporništva $\left(C O I N^{24}\right)$, in sicer v razmerah asimetričnega bojišča, v kakršnih je tedaj deloval Isaf.

Aprila 2013 se je element ESD v Večnacionalnem združenem centru za usposabljanje $\left(J M T C^{25}\right)$ v Hohenfelsu v Nemčiji udeležil štiritedenskega skupnega urjenja vseh mednarodnih elementov Desete skupne bojne skupine za specialno delovanje. Na urjenju je element uspešno potrdil interoperabilnost z elementi specialnih sil Nata, $\mathrm{s}$ čimer je bil izpolnjen še zadnji uradni pogoj za napotitev v MOM.

\section{Napotitev in umestitev v Deseto skupno bojno skupino za specialno delovanje}

Sredi septembra 2013 se je glavnina elementa ESD premaknila iz Slovenije v Afganistan. Po razmestitvi na končne lokacije na območju delovanja ${ }^{26}$ so se pripadniki elementa za podporo poveljevanju začeli vključevati v svoje delovno okolje, pripadniki bojnega dela pa so se začeli pripravljati na vzpostavitev operativne pripravljenosti za delovanje. Med pripravami so se seznanili z obveščevalno-taktično situacijo v provinci, z geografsko razporeditvijo sil Desete skupne bojne skupine za specialno delovanje in z razmestitvijo konvencionalnih koalicijskih enot $\left(B S O / I^{27}\right)$ in afganistanskih varnostnih sil $\left(A N S F^{28}\right)$ ter z njihovimi zmogljivostmi.

V tem obdobju je bilo bataljonsko poveljstvo Desete skupne bojne skupine za specialno delovanje nameščeno v vojaškem oporišču Camp Vose (znotraj Campa Phoenix) v Kabulu. Pod njim sta delovali dve odredni poveljstvi, in sicer Odred za specialno delovanje zahod $(S O T G-W) \mathrm{v}$ provinci Logar in Odred za specialno delovanje vzhod (SOTG-E). Drugi je bil nameščen v vojaškem oporišču v Jalalabadu $\left(\mathrm{JAF}^{29}\right)$ v provinci Nangarhar. Odred za specialno delovanje vzhod je bil oktobra 2013 nadrejeno poveljstvo naše skupne taktične skupine za specialno delovanje (v nadaljevanju TSSD) province Laghman, poleg tega pa še skupnim TSSD v provincah Nangarhar, Kapisa in Kunar. Za razumevanje obsega naj navedem še, da je Deseta skupna bojna skupina za specialno delovanje med delovanjem elementa ESD štela približno 1500 koalicijskih in afganistanskih pripadnikov.

\footnotetext{
23 3-10 SFG(A): 3rd Battalion 10th Special Forces Group (Airborne).

${ }^{24}$ COIN: Counter Insurgency Operations.

${ }^{25}$ JMTC: Joint Multinational Training Center.

${ }^{26}$ Dva pripadnika v bataljonskem poveljstvu Desete skupne bojne skupine za specialno delovanje, dva pripadnika v Odrednem poveljstvu za specialno delovanje vzhod ter štirinajst pripadnikov bojnega in podpornega dela $v$ vojaškem oporišč Mehtar Lam v provinci Laghman.

${ }^{27}$ BSO/I: Battle Space Owner/Integrator (po prenosu odgovornosti za varnost afganistanskim varnostnim silam so imele konvencionalne koalicijske sile funkcijo Battle Space Integrator"in ne več Battle Space Owner, kar je pomenilo, da so namesto bojnega delovanja zagotavljale podporo afganistanskim varnostnim silam).

${ }^{28}$ ANSF: Afghanistan Security Forces.

29 JAF: Jalalabad Air Field.
} 


\section{Delovanje}

Element ESD je bil napoten v Isaf z nalogo izvajanja ene izmed temeljnih oblik specialnega delovanja, imenovane Vojaška pomoč $\breve{c}^{30}$ (Nato termin Military Assistance).

Zaradi boljšega razumevanja taktičnega delovanja v praksi bomo za začetek povzeli nekaj normativnih opredelitev za izvajanje specialnega delovanja SV. Njeno specialno delovanje je opredeljeno z Vojaško doktrino, ki ga opredeljuje kot način bojnega delovanja, ki »/.../ obsega nekonvencionalne vrste bojnega delovanja, direktne akcije, specialno izvidovanje, obveščevalno dejavnost, protiteroristično delovanje, psihološko delovanje ter bojno iskanje in reševanje. Vse aktivnosti specialnih sil so usmerjenje v vojaške cilje« (Furlan idr., 2006, str. 50).

Vojaška pomoč kot ena izmed oblik specialnega delovanja spada v nekonvencionalno vrsto bojnega delovanja in je kot takšna opredeljena tudi s področno doktrino oziroma SVS Stanagom 2523(1) Združena zavezniška doktrina specialnih operacij ${ }^{31}$.

Vojaška pomoč v definiciji obsega zelo različne ukrepe, ki podpirajo prijateljske sile $\mathrm{z}$ organizacijo usposabljanja, svetovanjem, mentorstvom ali skupnim delovanjem. Obsega tudi gradnjo zmogljivosti prijateljskih sil, interakcijo z lokalnimi, regionalnimi in nacionalnimi oblastmi ali strukturami ter civilno-vojaško sodelovanje, ki je namenjeno predvsem vplivanju na lokalno prebivalstvo. Vojaška pomoč obsega predvsem:

- usposabljanje: aktivnosti usposabljanja izbranih posameznikov in enot za taktično delovanje, skupno delovanje rodovskih in komponentnih sil ter gradnjo nacionalnih zmogljivosti za usposabljanje lastnih sil;

- svetovanje: aktivnosti, ki izboljšujejo delovanje posameznih prijateljskih akterjev, in sicer z aktivno udeležbo ter zagotavljanjem izkušenj, namenjeno pa je doseganju operativnih in strateških ciljev;

- mentorstvo/sodelovanje: aktivnosti manjših skupin specialistov, ki tesno sodelujejo z izbranimi partnerskimi elementi in jim dajejo usmeritve za izvajanje vojaških ali varnostnih operacij.

V praksi je Deseta skupna bojna skupina za specialno delovanje s svojimi skupnimi TSSD sodelovala $\mathrm{s}$ specialnimi policijskimi enotami na ravni provinc, tako imenovanimi Provincial Reaction Company oziroma skrajšano $P R C^{11}$. To so vojaško organizirane posebne policijske enote, namenjene predvsem ukrepanju ob hujših varnostnih grožnjah in izvedbi aretacij, pri katerih se pričakuje oborožen odpor. Kljub vojaški organiziranosti pa $P R C$ niso namenjeni za izvajanje bojnega delovanja v vojaškem smislu, saj nimajo svoje težje oborožitve in specifične rodovske podpore, ki ju imajo vojaške enote. Tako je bila ena izmed temeljnih nalog TSSD povezovanje različnih afganistanskih nacionalnih varnostnih struktur in Isafa za izvedbo zahtevnejših nalog, pri katerih se je pričakoval močnejši odpor nasprotnika.

\footnotetext{
${ }^{30}$ Vojaška pomoč je kot ena izmed treh temeljnih oblik specialnega delovanja opredeljena tudi z dokumentom SVS Stanag 2523(1): Združena zavezniška doktrina specialnih operacij (Allied Joint Doctrine for Special Operations).

${ }^{31}$ Nato AJP 3.5 Allied Joint Doctrine for Special Operations.
} 
Spekter nalog skupnih TSSD je bil zelo širok. Uradno ime ${ }^{32}$ specialnih sil Nata je bilo Tactical Train, Assist and Advise.

Začnimo s funkcijo Train, torej z usposabljanjem. Za razporeditev v enote $P R C$ morajo afganistanski policisti uspešno opraviti temeljno usposabljanje v enem izmed treh vadbenih centrov specialnih policijskih enot ${ }^{33}$. Po razporeditvi v posamezne enote $P R C$ so proces usposabljanja in urjenja prevzele TSSD. Te so individualno usposabljale in urile policiste $\mathrm{v}$ splošnih in specialističnih individualnih veščinah. V nadaljevanju so izvajale enotovno usposabljanje, hkrati pa tudi usposabljanje poveljniškega kadra za načrtovanje in izvedbo taktičnih nalog.

Assist, torej pomoč, kot že ime pove, je bila pomoč pri načrtovanju, organizaciji in izvedbi taktičnih nalog. V fazi načrtovanja in organizacije so pomagale pri izvajanju ciljenja $^{34}$ in zagotavljanju kakovostnih obveščevalnih podatkov, ki so jih hkrati z afganistanskimi varnostnimi silami zbirale različne strukture Isafa in druge varnostne organizacije iz koalicijskih držav, ki so bile navzoče na območju delovanja. Ena ključnih funkcij je bila tudi pomoč pri zagotavljanju različnih vrst podpore, bodisi afganistanskih varnostnih sil bodisi Isafa. Vrsta podpore je bila odvisna od tipa posamezne naloge, zahtevnosti taktične situacije in geografskega okolja (včasih tudi od vremena). V praksi je lahko variirala od razmeroma preprostega protiminskega čiščenja komunikacij in zagotavljanja sil za hitro posredovanje do zelo vsestranske zračne podpore. Ta je navadno vsebovala več različnih elementov, kot so:

- zračni nadzor cilja ali območja, ki so ga izvajala različna brezpilotna letala $\left(\mathrm{UAV}^{35}\right)$ ali različne platforme zračnih plovil s posadko $\left(\mathrm{ISR}^{36}\right)$,

- elektronski nadzor cilja ali območja $\left(\mathrm{EW}^{37}\right)$,

- različne oblike ognjene podpore iz zraka $\left(\mathrm{CAS}^{38}\right)$,

- zračna evakuacija ranjenih in poškodovanih $\left(\mathrm{MEDEVAC}^{39}\right)$.

Pri načrtovanju in organizaciji nalog je bil najpomembnejši del odobritev, ki je vedno potekala hkrati, in sicer po afganistanski nacionalni ter Isafovi liniji poveljevanja in kontrole. Po afganistanski liniji je potekala od PRC prek poveljnika

${ }_{32}$ Delovanje Isafa je bilo opredeljeno z dokumentom specialnih sil Isafa SOP 306: ISAF SOF Operations Management.

${ }^{33}$ Kot je zapisano v podpoglavju 3.2., je SV v Vadbenem centru specialnih policijskih enot v Wardaku sodelovala od aprila 2012 do septembra 2013, in sicer s štirimi pripadniki ESD na rotacijo.

${ }^{34}$ Po mnenju avtorja slovenski prevod zavezniškega termina targeting ne vključuje večplastnosti te aktivnosti, ki v zelo posplošenem smislu pomeni usmerjanje delovanja z izbiro ciljev.

35 UAV: Unmanned Aerial Vehicles.

${ }^{36}$ ISR: Intelligence, Surveillance \& Reconnaissance.

${ }^{37}$ EW: Electronic Warfare.

${ }^{38}$ CAS: Close Air Support. Zagotavljali so jo bodisi helikopterji (Arial Weapons Teams ali krajše AWT $s$ helikopterji AH-64D) bodisi letala, kot so A-10, F-15E, F-16, B-1B in AC $130 \mathrm{H} / \mathrm{U}$. Vsaka izmed teh zračnih oborožitvenih platform ima svoje prednosti in slabosti, tako da je bilo predvsem od naloge, geografskega okolja in vremena odvisno, katere platforme bo SOTU uporabila. Element ESD je v resnici opravljal naloge tudi z osmimi različnimi platformami naenkrat, ki jih je v sodelovanju s specialistom OS ZDA nadziral in usmerjal slovenski usmerjevalec združenega ognja (Joint Tactical Air Controller).

${ }^{39}$ MEDEVAC: Medical Evacuation. Treba je poudariti, da je šlo za dva ločena sistema, enega za pripadnike koalicijskih sil in drugega za pripadnike afganistanskih varnostnih sil. 
provincialne policije $\left(\mathrm{PcoP}^{40}\right)$ do guvernerja province $\left(\mathrm{PGov}^{41}\right)$. Po Isafovi liniji poveljevanja in kontrole pa je potekala od TSSD prek (v našem primeru) Odreda za specialno delovanje vzhod in Desete skupne bojne skupine za specialno delovanje do poveljstva specialnih sil Isafa. Hkrati s procesom odobritve sta bila opravljena tudi usklajevanje in sinhronizacija z BSI/O11, in sicer prek koalicijskih taktičnih enot na geografskem območju delovanja do regionalnega poveljstva vzhod $(R C-$ $\left.E^{42}\right)$ v našem primeru. Tu je treba opomniti tudi, da komponenta specialnih sil Isafa ni bila podrejena konvencionalnim njegovim silam oziroma je bila enake ravni kot Združeno poveljstvo Isafa (IJC ${ }^{43}$ ). TSSD tako za izvedbo nalog ni potrebovala odobritve regionalnega poveljstva. Ker pa ji je to navadno zagotavljalo različne oblike podpore, sta morala biti za izvedbo posamezne naloge opravljena vsaj usklajevanje in sinhronizacija delovanja z drugimi enotami konvencionalnih sil na istem geografskem območju.

Zaradi operativnih ali strateških učinkov, včasih pa tudi zaradi politično občutljivih ciljev, so bili načrti za vsako posamezno nalogo podrobno pregledani, in sicer na vseh navedenih ravneh, izvedba pa je bila navadno odobrena na operativni oziroma $\mathrm{v}$ določenih politično bolj občutljivih primerih tudi na strateški ravni.

Pri izvedbi naloge je TSSD pomagala pri taktičnem usklajevanju in sinhronizaciji vseh elementov podpore. V tem delu je prišla do izraza funkcija Advise, torej svetovanje. Vodstvo nad izvedbo nalog je bilo izključno v pristojnosti afganistanskih sil. Tako je bil poveljujoči bodisi poveljnik PRC bodisi neposredno PCoP. TSSD je tako pri izvedbi naloge opravljala funkcijo neposrednega taktičnega svetovanja (Tactical Advise) partnerskim silam. To pomeni, da je bila TSSD navzoča na območju delovanja in je spremljala delovanje partnerskih sil ter jim svetovala v smislu taktičnega delovanja. Hkrati je opravljala tudi sprotno taktično usklajevanje in sinhronizacijo elementov podpore, ki so ju zagotavljale koalicijske sile.

Želel bi poudariti, da je TSSD pri izvedbi naloge zaradi političnih omejitev afganistanske vlade uporabljala oboroženo silo samo za samoobrambo, in sicer za svojo zaščito ali zaščito svojih afganistanskih partnerjev, v drugem primeru predvsem z uporabo ognjene podpore iz zraka, ki pa je morala biti zaradi strogih omejitev pravilno stopnjevana. Pravila delovanja specialnih sil Isafa so bila zaradi političnih implikacij zelo stroga. Neposredni nadzor nad izvedbo in spoštovanjem pravil delovanja so imele prek različnih zračnih platform tudi vse ravni udeleženih poveljstev specialnih sil Isafa ( $\mathrm{v}$ našem primeru Odred za specialno delovanje vzhod, Deseta skupna bojna skupina za specialno delovanje in poveljstvo specialnih sil Isafa). Tako so lahko nadrejena poveljstva neposredno spremljala in nadzirala izvedbo nalog ter zagotavljala dodatno pomoč pri usklajevanju in sinhronizaciji bojišča z drugimi strukturami Isafa, če je bilo treba. Ob izrednih dogodkih, kot so

\footnotetext{
${ }^{40}$ PcoP: Provincial Chief of Police.

${ }^{41}$ PGov: Provincial Governor.

${ }^{42}$ RC-E: Regional Command East.

${ }^{43}$ IJC: ISAF Joint Command.
} 
na primer civilne žrtve, pa so izvajala tudi vse potrebne postopke za preprečevanje hujših političnih posledic.

Vojaška pomoč specialnih sil je tako v primerjavi s konceptom operativnih skupin za mentorstvo in povezave $\left(\mathrm{OMLT}^{44}\right)$ konvencionalnih sil večplastna oziroma neposrednejša oblika delovanja za doseganje neposrednih učinkov v varnostnem okolju. Elementi specialnih sil Isafa so enako kot elementi skupine OML opravljali naloge usposabljanja, pomoči in svetovanja afganistanskim varnostnim silam za izgradnjo zmogljivosti. Drugi del njihovih nalog pa je obsegal proces ciljenja in zagotavljanje neposredne bojne podpore za usmerjanje njihovega bojnega delovanja ${ }^{45}$.

Treba je opozoriti tudi, da je TSSD zaradi političnih omejitev, ki jih je postavila afganistanska vlada, v zadnji fazi operacije Isafa opravljala le partnerske oziroma svetovalne naloge in ne več nalog neposrednega bojnega delovanja. Tako je sodelovala predvsem s policijskimi silami PRC, vendar se je zaradi doseganja večjih neposrednih učinkov na bojišču povezovala tudi z drugimi strukturami afganistanskih varnostnih sil, kot so National Directorate of Security11 (NDS), Police Investigation and Surveillance Units11 (ISU), Afghanistan National Army11 (ANA), Afghanistan Local Police11 (ALP) in z nekaterimi drugimi. Hkrati se je povezovala tudi s konvencionalnimi koalicijskimi silami in z različnimi drugimi varnostnimi strukturami koalicijskih držav, ki so delovale na tem območju odgovornosti. TSSD je tako z delovanjem svojih partnerskih enot opravljala naloge z višjo stopnjo tveganja na taktični ravni, vendar z njihovim vplivom na operativni, strateški ali celo politični ravni. Med drugim je bil ravno zaradi tega tudi proces odobritve nalog veliko bolj zapleten in je potekal na operativni ali celo strateški ravni. Če povzamemo, TSSD je delovala s povezovanjem različnih afganistanskih nacionalnih ter mednarodnih varnostnih struktur oziroma sil, in sicer tako na horizontalni kot tudi na vertikalni ravni, kar se je odražalo na operativni in celo strateški ravni.

Primer, ko je delovanje specialnih sil na taktični ravni imelo vpliv na politični, se je zgodil decembra 2013, ko je neimenovana enota koalicijskih specialnih sil prekršila omejitev vstopa v afganistansko domovanje. Omejitev, ki jo je postavila afganistanska vlada, ni bila jasno opredeljena, tako da so jo koalicijske sile razumele drugače kot afganistanska stran. Posledica je bila, da je afganistanski predsednik Karzai zahteval zaustavitev vseh operacij koalicijskih specialnih sil (tako Isaf kot tudi sil operacije Trajna svoboda $)^{46}$. Ta je trajala skoraj tri tedne, dokler ni bil sprejet politični konsenz z jasno opredelitvijo omejitve vstopa koalicijskih sil v afganistanska domovanja. Od

\footnotetext{
${ }^{44}$ OMLT: Operational Mentor and Liaison Team.

${ }^{45}$ Del poslanstva specialnih sil Isafa, ki se je nanašal na delo z afganistanskimi varnostnimi silami, se je glasil (navajam vizvirniku, da ne bi prišlo do morebitne izgube pomena zaradi prevoda): „Work by, with, and through PRC's to achieve layered and synergistic effects in the battle space with other ISAF and ANSF counterparts".

${ }^{46}$ Predvidevanja so tudi, da je predsednik Karzai izkoristil dogodek za politični pritisk na ZDA, in sicer za zavlačevanje podpisa sporazuma, ki bi oboroženim silam ZDA in tudi drugim mednarodnim varnostnim silam omogočil prisotnost v državi po letu 2015.
} 
takrat so lahko koalicijske specialne sile vstopile v afganistanska domovanja samo zaradi neposredne samoobrambe ali če so dobile izrecno povabilo ali prošnjo lastnika za vstop. Poveljniška struktura Isafa pa je med zaustavitvijo operacij zagotovila, da so poveljniki taktičnih enot podrobno poznali in razumeli postavljene omejitve.

Sklep Delovanje ESD v specialnih silah Isafa pomeni vrhunec dolgoletnega razvoja enote in takšnih zmogljivosti SV. SV in predvsem ESD sta z uspešno napotitvijo elementa ESD v specialne sile Isafa pridobili neprecenljive izkušnje za skupno združeno specialno delovanje $\mathrm{e}^{47} \mathrm{v}$ neposredno podporo protiuporniškemu bojnemu delovanju afganistanskih varnostnih sil in s tem hkrati tudi najboljšo mogočo potrditev interoperabilnosti, usposobljenosti ter prilagodljivosti tako posameznikov kot tudi enote. S potrditvijo svojih zmogljivosti v zahtevnem mednarodnem okolju je ESD dokazala, da je strateški koncept delovanja specialnih sil SV, opredeljen z Vojaško doktrino, uresničljiv in da so rešitve, na katerih temelji njihova organizacija, pravilne.

Z delovanjem v skupnem združenem okolju operacije Isafa je SV potrdila ciljne zmogljivosti specialnih sil SV za izpolnjevanje obveznosti RS do sistema kolektivne obrambe Nata.

Potrdila je svoj položaj tudi v strukturi specialnih sil Nata in partnerstvo s specialnimi silami oboroženih sil ZDA, ki delujejo pod komponentnim poveljstvom ameriških specialnih sil v Evropi (US SOCEUR ${ }^{48}$ ). Prav tako je prispevala k vzdrževanju in širitvi povezav Natovih specialnih sil ter pri nadgradnji interoperabilnosti. Oba elementa sta bistvenega pomena za razvoj in delovanje specialnih sil SV v prihodnosti. Naj poudarimo, da so pridobljene izkušnje na področju delovanja specialnih sil, ob upoštevanju varnostnih teženj v neposredni soseščini Balkana in v regiji Jugovzhodne Evrope, pomembne tudi za domače varnostno okolje.

1. Beršnak, K., 2010. Preoblikovanje vloge in načinov delovanja enot za specialno delovanje zveze Nato v povezavi z evolucijo tipologije vojskovanja. Diplomsko delo, Maribor: Fakulteta za varnostne vede.

2. Beršnak, K. 2014. SVNKON 20 ISAF - Delovanje elementa Enote za specialno delovanje. Revija Obramba. Ljubljana: Defensor, str. 9-11.

3. Državni zbor RS, 2004. Resolucija o splošnem dolgoročnem programu razvoja in opremljanja Slovenske vojske - ReSDPRO SV. Ljubljana: Uradni list RS, št. 89/07.

4. Državni zbor RS, 2004. Zakon o obrambi (ZoObr). Ljubljana: Uradni list RS, št. 103/2004.

5. Državni zbor RS, 2010. Resolucija o strategiji nacionalne varnosti Republike Slovenije (ReSVN-1). Uradni list RS, št. 27/10.

6. Državni zbor RS, 2010. Resolucija o splošnem dolgoročnem programu razvoja in opremljanja Slovenske vojske do leta 2025 (ReSDPRO SV 2025). Uradni list RS, št. 99/10.

\footnotetext{
${ }^{47}$ Skupno združeno specialno delovanje; element ESD je v večnacionalni Deseti skupni bojne skupine za specialno delovanje sodeloval z zračno komponento koalicijskih sil operacije Trajna svoboda, zaradi doseganja večjih neposrednih učinkov na bojišč pa se je neposredno povezoval tudi z drugimi strukturami afganistanskih varnostnih sil in drugimi varnostnimi organizacijami koalicijskih držav (v smislu termina interagency operations - glej vir JSOU, 2013).

${ }^{48}$ SOCEUR: Special Operations Command Europe.
} 
7. Furlan, B., Rečnik, D., Vrabič, R., Maraš, V., Cerkovnik, J., Špur, B., Šonc, M., Tušak, M., Ivanuša, M., Gorjup, B., Kojadin, M., Lasič, K., in Unger, M., 2006. Vojaška doktrina. Ljubljana: Defensor.

8. Garb, G., 2012. Vloga finančnih virov pri uveljavljanju sodobne varnostne paradigme na obrambnem področju v izbranih državah. Ljubljana: Generalštab Slovenske vojske: Sodobni vojaški izzivi 14/št. 2, str. 59-78.

9. Joint Special Operations University, 2013. Special Operations Forces Interagency Counterterrorism Reference Manual. Tampa, Florida: The JSPU Press.

10. MO, 2009. SVS STANAG 2523(1): Združena zavezniška doktrina specialnih operacij (AJP-3.5). Ljubljana: $M O$.

11. MO, 2015. Predlog, da v duhu varčevanja Slovenija izstopi iz zveze Nato-odgovor Ministrstva za obrambo. Ljubljana: št. 092-55/2012-70 z dne 2. 2. 2015. http://predlagam. vladi.si/webroot/files/6332_PVS\%206332\%20MO.pdf, 3. 5. 2015.

12. North Atlantic Council, 2002. Prague Summit Declaration. http://www.nato.int/docu/ pr/2002/p02-127e.htm, 3. 5. 2015.

13. North Atlantic Council, 2006. Riga Summit Declaration. http://www.nato.int/docu/ pr/2006/p06-150e.htm, 3. 5. 2015.

14. NSCC, 2008. The Nato Special Operations Forces Study. NSCC, Mons.

15. Paternus, U., 2010. Preoblikovanje vojaških specialnih enot držav zveze Nato. Magistrsko delo, Ljubljana: Fakulteta za družbene vede.

16. Prezelj, I., Kopač, E., Vuga, J., Žiberna, A., Kolak, A., Grizold, A., 2015. Military Transformation as Perceived by Experts. The Journal of Slavic Military Studies 28/št.1, str. 23-47, DOI: 10.1080/13518046.2015.998120.

17. Pripadniki elementa ESD SVNKON 20 ISAF, 2014. Pripadniki elementa ESD SVNKON 20 ISAF prejeli "Combat Infantryman Badge". Slovenska Vojska: uradni blog. http:// slovenskavojska.blogspot.com/2014/05/pripadniki-elementa-esd-svnkon-20-isaf.html, 5. 5. 2015.

18. Rode, A., Beršnak, K., in Langerholc, B., 2011. Enota za specialno delovanje Slovenske vojske - odgovor na sodobne izzive. Ljubljana: Generalštab Slovenske vojske: Sodobni vojaški izzivi 13/št. 3, str. 165-181.

19. Vlada RS, 2005. Srednjeročni obrambni program 2005-2010. Ljubljana: št. 802-001/2004-89 z dne 22. 6. 2005.

20. Vlada RS, 2006. Srednjeročni obrambni program 2007-2012. Ljubljana: št. 803-2/200658 z dne 27. 11. 2006.

21. Vlada RS, 2013. Srednjeročni obrambni program 2013-2018. Ljubljana: št. 80300$1 / 2013 / 3$ z dne 1. 2. 2013

22. Šteiner, A., 2013. Projektiranje preoblikovanja strukture sil vojske. Ljubljana: Generalštab Slovenske vojske: Sodobni vojaški izzivi 15/št. 4, str. 51-73. 